\title{
Cultural Differences in Chinese and English Address Terms
}

\author{
Qian Chen \\ Department of Foreign Language, Dezhou University, Dezhou, China \\ Email: cqbhh@126.com
}

\begin{abstract}
Chinese and English address terms vary in types and characteristics. Chinese address system is more complex with more terms and a wider scope of application. As a special part of language, address terms are closely related to culture. Through the comparison between the Chinese and English address terms, the social and cultural elements embodied in the difference of the two systems can be revealed. The cultural difference in value concept, sense of hierarchy and sense of equality, and the different attitude toward the role of family greatly influence the difference between Chinese and English address terms.
\end{abstract}

Index Terms - address term, comparison, cultural difference

Language is the carrier of culture. Address term as a special part of language is closely related to culture. "An address term, or address form, refers to the word o words used to address somebody in speech or writing" (Dai, 2002, p127). Address term, which can reflect the relationship between speakers and the cultural connotation, is a kind of special language symbol. Compared with English address system, the Chinese address system is more complex with more types and a wider scope of application. Their differences are closely related to the different social and cultural background of their own.

\section{THE COMPARISON BETWEEN CHINESE AND ENGLISH ADDRESS SYSTEMS}

Chinese and English address systems are different but both of them can be classified into two types: kinship address and address in social intercourse.

\section{A. Kinship Address}

Kinship address can be further divided into two types: address of relatives and address of the non-blood.

a. Address of relatives

In modern Chinese, relative titles can also indicate people's status. For example, position in the family hierarchy (people of parents' generation: 伯, 舅, people of the same generation: 哥, 堂弟, 表姐), paternal or maternal relatives: 姑, 姨, blood relatives or relation by marriage: 哥, 嫂子.However, in English relative titles are more general and ambiguous. A term often has several meanings. “sister” can be 姐姐 or 妹妹; ”grandmother” is either 奶奶 or 外婆; “uncle” may be 叔、伯、 舅、姑父;”cousin” is even omnipotent: 堂兄弟姐妹、表兄弟姐妹 are all cousins. There is neither sex distinction.

In Chinese, brothers and sisters often address each other according to the age, such as 二哥, 四妹. But in English-speaking countries people conventionally call names. They even directly call their parents' brother or sister their names.

b. Address of the non-blood

In Chinese a considerable part of relative titles can address people who have no blood relationship, such as 叔叔, 爷爷, 大哥, 伯母. We can see that the extending of kinship address is very common and the whole society can be related by kinship address. On the contrast, English kinship address is barely extended. "aunt" and "uncle" can only be used to address familiar or intimate persons, and they are usually followed by addressee's name, for example, Uncle Tom, Aunt Lucy.

\section{B. Address in Social Intercourse}

Address in social intercourse is classified into the following types:

a. Post and rank address

Generally speaking, in Chinese the words that express social status, such as job, post, professional title, can all be used in the appellation. Job appellation such as teacher, driver, lawyer; post appellation such as director, minister, manager, secretary; professional title appellation such as engineer, accountant, lecturer; title appellation such as general, colonel. They are often used with names to show speaker's respect. On the contrary, in English post and rank address is not often adopted. The form " title + last name" is often used to address imperial kinsmen, government officials and people in religion and military circle, for example, President Bush, Prince William, Pope John. The form "common profession or post +last name" is used to call doctors and professors, such as Doctor Smith. For the common address form “老师”, we can not find its corresponding address form in English. In English-speaking countries students call male teacher "Sir" and female teacher "Miss" or "Mrs.", such as Mr. Brown, Miss Stone. Sometimes they simply call their teachers 'Sir' or "Miss". Generally speaking, in Chinese post and rank address is much more extensive and complicated than in English.

b. Name address 
In Chinese name address is often used among the same generation. Among the kiths and kin pet names are often used such as 小丽, 亮亮. Only the lover or the close relative uses the first name alone to address, for example, 丽、亮. The difference of address demonstrates the degree of familiarity.

In English name address is an important component of the whole address system. People's last name, first name, full name and pet name exist simultaneously. To intimate speakers, nickname or pet names are used more often. When Americans meet a person for the first time, they often ask him or her to call their first name. They even address parents and superior their first names. In Chinese first name alone is a very affectionate form of address and hence we should use it carefully between different sexes to avoid misunderstanding.

c. General term

English general term mainly includes Mr., Mrs., Miss, Ms, Madam, sir and lady. The former three are often used with last name. "Ms", a respecting term appearing in recent decades, is the result of Women Emancipation. The Chinese general term is as follows: 同志、师傅、老师、先生、小姐、女士. In the past, “同志””师傅” was very popular. Their range of usage became narrowed recently.“老师”is used very widely. Many people whose jobs are not related to teaching are also called“老师”. “先 生”and”小姐” are used most frequently in social intercourse. One point we should pay attention is that “先生” in Chinese can be either male or female, for example, 杨㖓先生。It does not completely correspond with Mr. or Sir in English.

\section{SOCIAL AND CUltural DifFERENCES THAT DETERMINE THE DIFFERENT CHINESE AND ENGLISH ADDRESS TERMS}

"Basically the language is the result of a kind of culture and the society, so it must be understood in terms of culture and society" (Liu, 1998, p, 183).The language stems from culture and reflects this culture, and culture permeates in the language again. Chinese and English address systems are the results of inside social communication of each nationality, reflecting each nation's custom and culture. From the different address systems the following social and cultural differences in Chinese and English can be reflected:

\section{A. Difference in Value Concept}

Chinese culture recommends being modest, prudent and the spirit of devoting for others, while the western culture represented by British and American culture stresses individuality and puts emphasis on self-orientation and independence. So the core of Chinese communication is other-oriented while the core of western communication is self-oriented. The former puts the collective value in the highest position and the latter regards personal value highly. Consequently, Chinese use more respecting terms and modest words. They always like putting themselves in a lower position in communication in order to show courtesy, such as “晚辈”、“您”、“令尊”. In English, the respecting terms can be cut off.“您”and“你”can be both expressed as “you”. “晚辈”and“令尊”have no corresponding address forms in English.

\section{B. Difference in Sense of Hierarchy and Sense of Equality}

Because of the influence of the ancient Confucianism over Chinese culture, the thought of hierarchy still occupies an important position in social relationships. Chinese usually add the post appellation after the surname to show respect and the addressee's identities when addressing people who have posts. Higher authorities often address subordinates their names. In western culture, consciousness of equality is relatively strong. There is no stern idea of hierarchy. They address others by given name among ordinary people, colleague, the superior and the subordinate, parents and children. They usually ask others to call their first name in order to establish equal relationship with others. Mr./ Mrs./ Ms./Miss. is added before the surname if necessary. For example, they introduce the superior as “this is Mr. Wang, our dean”; while Chinese say “这是王主任”.

Chinese traditional society is a patriarchal one. Old and young are clearly demarcated among kinfolks. The seniority in the family is rigorously enforced. It is considered to be very rude for the younger generation to address the elder by name. In Chinese “老" represents a kind of qualification, dignity, and authority. Chinese often use “老” with surname to address others. People call elders “张老”“李老”while“老张”“老李”are used among the same generation to show they are familiar. But if we add "Old" before the surname of British or American to address them, it will make them feel baffled.

\section{Difference Regarding the Role of Family}

Family is the basic composition unit of the society and the relationship in family is the foundation of the complicated social relationships. In the history of China, such traditional idea as "raising sons to support one in one's old age" is deep-rooted, so the extended family makes up the basic unit of society. In kinship address the position in the family hierarchy is rigorously enforced and kinfolk's relation becomes more and more complicating. On the contrary for British and American, the basic family members only include parents and children; what's more, the big family has been replaced by the nuclear family because people have changed the view of bearing. In this way the number of kinfolks were reduced obviously; the relationship among relatives became more and more simple, and the appellation is simplified too.

In addition, Chinese subconsciously think family enlarges the society. Traditional interpersonal relationships in China are actually tied by kindred. In this kind of interpersonal relationships, people have extremely strong attachment to family. So in Chinese address terms, kinship address is greatly extended to outsiders. A child can call strangers “叔叔”、“阿姨”. Adults can call others “大哥”、“伯母”. But westerners think “a man’s home is his castle”, namely a person’s family is sacred and inviolable, therefore the British and American are not used to bringing the non-blood into the network of relatives. 


\section{CONCLUSION}

Address terms is the precursor of communication and an essential component of language. Stemming from different nationalities, the Chinese and English address systems are formed in different language systems, and exist simultaneously in different social cultural background for a long time. So there exists great difference which would make foreigners confused. The cultural difference in value concept, sense of hierarchy and sense of equality, and the different attitude toward the role of family greatly influence the difference between Chinese and English terms. Both language learners and users should know well about the English and Chinese address terms, including the social and cultural elements embodied in them. It's necessary for successful cross-cultural communication.

\section{REFERENCES}

[1] Dai Weidong \& He Zhaoxiong. (2002). A Concise Course Book on English Linguistics. Shanghai: Shanghai Foreign Language Education Press.

[2] Kramsch, Claire. (2003). Language and Culture. Shanghai: Shanghai Foreign Language Education Press.

[3] Kramsch, Claire. (1999). Context and Culture in Language Teaching. Shanghai: Shanghai Foreign Language Education Press.

[4] Liu Runqing. (1998). Selected Readings in Modern Linguistics. Beijing: Cartography Press.

[5] Nemetz, Gail L. (1988). Cross Cultural Understanding. San Francisco: Prentice Hall International Ltd.

[6] Porter, R. E \& Samovar, L. A. (2002). Communication Between Cultures. Beijing: Foreign Language Teaching and Research Press.

[7] Scollon, R and Scollon, S.W. (2000). Intercultural Communication: A Discourse Approach. Beijing: Foreign Language Teaching and Research Press.

[8] Widdowson, H. G. (1998). Teaching language as Communication. London: Oxford University Press.

Qian Chen was born in Leling, China in 1974. She received her M.A. Degree in English language teaching from Hebei Normal University, China in 2002.

She is currently an associate professor in English Department, De Zhou College, Dezhou, China. Her research interests include English language teaching and American literature.

Prof. Chen twice got the Prize awarded by De Zhou Social Science Association for her published articles. 